\title{
Non-Hodgkin's lymphoma in a chronic myelocytic leukemia patient treated with imatinib
}

Imatinib alan bir kronik miyeloid lösemi olgusunda gelişen non-Hodgkin lenfoma

\author{
Semra Paydaş${ }^{1}$, Berna Bozkurt Duman ${ }^{1}$, Melek Ergin ${ }^{2}$ \\ ${ }^{1}$ Department of Oncology, Faculty of Medicine, Çukurova University, Adana, Turkey \\ ${ }^{2}$ Department of Pathology, Faculty of Medicine, Çukurova University, Adana, Turkey
}

\begin{abstract}
Imatinib is an important example of tyrosine kinase inhibitors (TKIs) used in clinical practice. Imatinib blocks the ATP binding site of the Bcr-Abl fusion protein and selectively inhibits Bcr-Abl tyrosine kinase (TK) activity. Treatment of chronic myelocytic leukemia (CML) with imatinib is encouraging and it has an acceptable toxicity profile, and as such has changed the management of CML during the last decade. As with all drugs used in clinical practice, side effects of imatinib have been reported in studies with extended follow-up periods. In addition, some neoplastic disorders have been reported to occur during imatinib therapy. Herein we present a CML case that developed non-Hodgkin's lymphoma (NHL) while receiving imatinib treatment. (Turk J Hematol 2011; 28: 232-4)
\end{abstract}

Key words: Imatinib, chronic myelocytic leukemia, non-Hodgkin's lymphoma

Received: July 04, 2009

Accepted: March 22, 2010

\section{Özet}

İmatinib klinikte kullanılan tirozin kinaz (TK) inhibitörlerinin önemli bir örneğidir. Bcr Abl füzyon proteininin ATP bağlayan bölgesini bloke eder ve selektif olarak TK aktivitesini bloke eder. Kronik miyeloid lösemide (KML) imatinib'e yant heyecan vericidir ve kabul edilebilir toksisite profiline sahiptir. Bu özellikleri ile son on yılda KML yönetimini değiştirmiştir. Klinikte kullanılan her ilaçta olduğu gibi bazı yan etkiler uzun süreli takipte rapor edilmektedir. Diğer yan etkilerine ek olarak, imatinib tedavisi sırasında bazı neoplastik bozukluklar yayımlanmıştır. Burada KML nedeniyle imatinib almakta iken non-Hodgkin lenfoma (NHL) gelişen bir olgu sunulmuştur.

(Turk J Hematol 2011; 28: 232-4)

Anahtar kelimeler: Imatinib, kronik miyeloid lösemi, non-Hodgkin lenfoma

Geliş tarihi: 04 Temmuz 2009

Kabul tarihi: 22 Mart 2010 


\section{Case}

A 49-year-old man that was diagnosed with chronic myelocytic leukemia (CML) 14 months earlier presented to our unit with the diagnosis of nonHodgkin's lymphoma (NHL). He had been treated with imatinib for 13 months and complete hematologic response was achieved within 1 month. Cytogenetic remission was noted at the 6th month of the therapy. One month before presenting to our hospital he was in complete molecular remission and experienced abdominal pain. Imatinib was withdrawn at that time. CT scans showed jejunal wall pathology and dilatation. Due to abdominal pain and distention, exploratory surgery was performed, including partial small bowel resection + side-toside anastomosis and feeding jejunostomy. Following that surgery he was referred to our unit. Written informed consent was obtained from the patient.

Physical examination showed pallor, the incision from abdominal surgery, and the jejunal feeding tube. There was no evidence of organomegaly. Laboratory test results were as follows: Hb: $11.2 \mathrm{~g} /$ $\mathrm{dL}$; total protein/albumin: 7.9/3.7 g/dL; LDH: $475 \mathrm{IU}$. CT scans of the thorax, abdomen, and pelvis showed small subpleural nodules in both lungs and jejunal wall thickening. The radiology department reported these lesions as leukemic infiltration.

A small bowel biopsy specimen obtained during surgery was reported as diffuse large B-cell lymphoma (DLBCL). The specimen showed diffuse infiltration by atypical large cells. The cells had a high N:C ratio and clumped chromatin (Figure 1). Immunohistochemical analysis showed that the tumor was positive for LCA and CD20, and was negative for myeloperoxidase, cytokeratin, and CD3. CD79a, bcl-2, bcl-6, and Ki-67 analyses were not performed due to the obvious DLBCL histopathology. The bowel biopsy specimen was also examined for Bcr-Abl and there was no evidence of its expression. Bone marrow biopsy was negative for lymphomatous infiltration. Systemic staging showed no other evidence of lymphomatous infiltration. The patient was treated with 6 cycles of R-CHOP chemotherapy and complete remission was achieved. After DLBCL therapy, imatinib was re-started; molecular remission was achieved and at the time this paper was written the patient was receiving standard imatinib treatment.

\section{Discussion}

Imatinib is an important choice of treatment in cases with CML and its clinical use is increasing in daily practice due to its efficaciousness; however, this drug has some side effects, as do other drugs. The most frequently affects the skin, liver, and bone marrow. Although very rare, some secondary neoplasms during imatinib therapy have been reported. Rapid CML-blastic crisis (CML-BC) has been reported in a few patients that received imatinib [1]. MDS and AML have also been reported in some patients during or following imatinib treatment [2-5]. The precise incidence of these secondary events is not known; in a large study, only 3 cases with secondary neoplasia among $1701 \mathrm{CML}$ cases treated with imatinib were reported [4]. Other neoplasias associated with imatinib treatment are squamous cell cancer and multiple myeloma [6,7].

Two cases of Epstein-Barr virus (EBV)-related lymphoproliferative disease (LPD) have been reported to date. The first case of EBV $(+)$ cutaneous B-cell LPD was published in 2003. In that case a rapidly progressing ulcerating tumor on the head developed; interestingly, spontaneous resolution of the tumor occurred after lowering the dose of imatinib from 500 to $400 \mathrm{mg} / \mathrm{d}$ [8]. In the second case LPD occurred after 30 months of imatinib treatment. Pancytopenia, fever, night sweats, and DIC were the first manifestations of the lymphoma while the first to occur while the patient was in complete molecular remission. Bone marrow biopsy showed EBV (+) LPD; however, the tumor did not resolve after discontinuation of imatinib therapy [9].

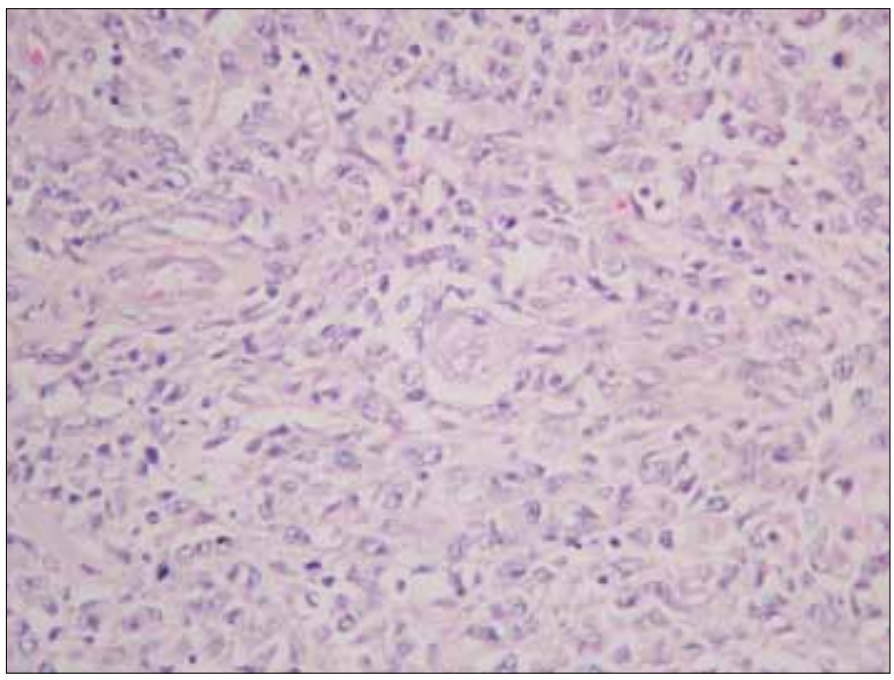

Figure 1. Lymphoma infiltration in the small bowel (H\&E, 200×) 
In the presented case the first symptom was abdominal pain. Repeated radiographic examinations showed jejunal thickening and the patient underwent exploratory surgery due to severe abdominal pain and subileus. It is well known that masses or nodules that develop in CML patients are indicative of a granulocytic sarcoma evidence of disease progression [10]. Upon presentation to the surgery department, the presented case was first diagnosed as leukemic infiltration; however, jejunal biopsy showed lymphoma. It is well known that granulocytic sarcoma histopathologically resembles NHL. The clinical working diagnosis of the presented case was leukemic infiltration-granulocytic sarcoma due to the accelerated/blastic phase of CML; however, histopathological findings were compatible with DLBCL. Myeloperoxidase was performed to exclude granulocytic sarcoma and the reaction was negative, as was Bcr-Abl. Although the cooccurrence of CML and DLBCL in the presented case cannot be ruled out, there were no symptoms indicative of small bowel disease at the beginning, and the abdominal symptoms and signs developed after 13 months of imatinib therapy. As such, to the best of our knowledge this is the first reported case of DLBCL in a CML patient treated with imatinib.

The etiology of secondary neoplasias in patients treated with imatinib is not known. In vitro studies have shown that imatinib inhibits the proliferation and activation of T-cells, and significantly reduces the antigen-triggered exposure of CD8 (+) T-cells in response to immunodominant CMV and EBV peptides [11]. One vitro study reported centrosome and chromosome aberrations in fibroblast cultures in association with varying concentrations of imatinib. These observations suggest a causative role for imatinib in clonal chromosomal aberrations in Bcr-Abl (-) progenitor cells [12]. In conclusion, although rare, secondary neoplastic disorders, including NHL, may be seen during imatinib treatment.

\section{Conflict of interest statement}

The authors of this paper have no conflicts of interest, including specific financial interests, relationships, and/or affiliations relevant to the subject matter or materials included.

\section{References}

1. Miyazaki K, Kon S, Watanabe T, Togano T, Ohsaka M, Suzuki Y, Danbara M, Horie R, Kanda Y, Maruta A, Higashihara M. Early blastic transformation within a year of imatinib treatment in 2 cases of chronic myeloid leukemia. Rinsho Ketsueki. 2007;48:297-304.

2. Andersen MK, Pedersen-Bjergaard J, Kjedsen L, Dufva $\mathrm{IH}$, Brondum K. Clonal Ph-negative hematopoiesis in CML after therapy with imatinib mesylate is frequently characterized by trisomy 8. Leukemia 2002;16:1390-5.

3. Chee YL, Vickers MA, Stevenson D, H olyoake TL, Culligan DJ. Fatal myelodysplastic syndrome developing during therapy with imatinib mesylate and characterised by the emergence of complex Philadelphia negative clones. Leukemia 2003;17:634-5.

4. Kovitz C, Kantarjian H, Garcia-Manero G, Abruzzo LV, Cortes J. Myelodysplastic syndromes and acute leukemia developing after imatinib mesylate therapy for chronic myelocytic leukemia. Blood 2006;108:2811-3.

5. Ross DM, Jackson SR, Browett PJ. Phialdelphia-negative secondary acute myeloid leukaemia during imatinib treatment for chronic phase myelocytic leukaemia. Leuk Lymphoma 2007;48:1231-3.

6. Baskaynak G, Kreuzer KA, Schwarz M, Zuber J, Audring H, Riess H, Dörken B, Coutre P. Squamous cutaneous epithelial cell carcinoma in two CML patients with progressive disease under imatinib treatment. Eur J Haematol. 2003;70:231-4.

7. Garipidou V, Vakalopoulou S, Tzimalos K. Development of multiple myeloma in a patient with chronic myelocytic leukemia after treatment with imatinib mesylate. Oncologist 2005;10:457-8.

8. Bekkenk MW, Vermeer MH, Meijer C, Jansen P, Middeldorp J, Stevens S, ReinWillemze. EBV-positive cutaneous B-cell lymphoproliferative disease after imatinib mesylate. Blood 2003;102:4243.

9. Leguay T, Foucaud C, Parrens M, Fitoussi O, Bouabdallah K, Belaud-Rotureau MA, Tabrizi R, Marit G, Pigneux A, Milpie N. EBV-positive lymphoproliferative disease with medullary, splenic and hepatic infiltration after imatinib mesylate therapy for chronic myeloid leukemia. Leukemia 2007;1-3.

10. Paydas S, Zorludemir S, Ergin M. Granulocytic sarcoma: 32 cases and review of the literature. Leuk Lymphoma 2006;47:2527-41.

11. Seggewiss R, Lore K, Greiner E, Magnusson MK, Price DA, Douek DC, Dunbar CE, Wiestner A. Imatinib inhibits T-cell receptor-mediated T-cell proliferation and activation in a dose-dependent manner. Blood 2005;105:2473-9.

12. Fabarius A, Giehl M, Frank O, Hochhaus A, Hehlmann R, Seifarth W. Induction of centrosome aberrations by imatinib in vitro. Leukemia 2005;1-6. 